Special issue of the 3rd International Conference on Computational and Experimental Science and Engineering (ICCESEN 2016)

\title{
Fluoride Levels in the Eastern Black Sea Basin Streams, Turkey
}

\author{
A. BAYRAm ${ }^{a, *}$, U. SATILMiş ${ }^{a}$, S.S. NAS ${ }^{b}$ AND B. Kemer ${ }^{c}$ \\ ${ }^{a}$ Karadeniz Technical University, Civil Engineering, Trabzon, Turkey \\ ${ }^{b}$ Gümüşhane University, Civil Engineering, Gümüşhane, Turkey \\ ${ }^{c}$ Karadeniz Technical University, Chemistry, Trabzon, Turkey
}

\begin{abstract}
The aim of this study is to monitor the fluoride ion $\left(\mathrm{F}^{-}\right)$, as well as chloride ion $\left(\mathrm{Cl}^{-}\right)$, variation in the Eastern Black Sea Basin streams, and to evaluate drinking water quality of these streams, with reference to national and international directives and guidelines. The water samples (240) were semimonthly collected from three surface water resources, namely from the Değirmendere and Galyan streams in Trabzon Province, the biggest city on the Southeastern Black Sea Coast with a total population of 768 417, and the Harşit Stream in Gümüşhane and Giresun provinces. The monitoring results have revealed that the average $\mathrm{F}^{-}$concentration had varied between 0.154 and $0.200 \mathrm{mg} / \mathrm{l}$ in the Değirmendere Stream and between 0.156 and $0.163 \mathrm{mg} / \mathrm{l}$ in the Galyan Stream, respectively. However, the treated stream waters had lower $\mathrm{F}^{-}$concentrations, varying between 0.010 and $0.080 \mathrm{mg} / \mathrm{l}$, than the untreated stream waters. In the Harsit Stream, the average $\mathrm{F}^{-}$concentrations were at relatively higher values, which ranged from 0.211 to $0.296 \mathrm{mg} / \mathrm{l}$, in the uppermost stations, however showed a steadily decreasing trend throughout the lowermost stations and fell from 0.230 to $0.141 \mathrm{mg} / \mathrm{l}$ due to the hydropower dam reservoirs, namely Torul, Kürtün, and Akköy, operated in the watershed. The average $\mathrm{Cl}^{-}$concentrations have varied between 2.00 and $6.48 \mathrm{mg} / \mathrm{l}$. On the one hand, the waters from the Değirmendere, Galyan, and Harşit streams are classified as high quality, considering the upper threshold values of $1.5 \mathrm{mg} \mathrm{F}^{-} / 1$ and $250 \mathrm{mg} \mathrm{Cl}^{-} / 1$. On the other hand, these streams can be regarded as the fluoride-poor water resources.
\end{abstract}

DOI: 10.12693/APhysPolA.132.861

PACS/topics: 92.40.Qk, 92.40.qf

\section{Introduction}

The fluoride ion $\left(\mathrm{F}^{-}\right)$concentrations in natural waters vary in relation to many factors, such as geological type, urban and industrial inputs, and the extent of withinriver and within-aquifer processing, as well as evaporative concentration. Worldwide $\mathrm{F}^{-}$concentrations vary from $<0.050$ to almost $2000 \mathrm{mg} / \mathrm{l}$ [1]. According to WHO [2], the minimum $\mathrm{F}^{-}$concentration in drinking-water should be approximately $0.5 \mathrm{mg} / \mathrm{l}$, with an optimal range of 0.5 to $1.5 \mathrm{mg} / \mathrm{l}$. In fact, fluoride is not essential for human growth and development but is helpful in the prevention of dental caries [3].

The chloride is a major ion found in natural waters in extremely variable concentrations, ranging from $<1 \mathrm{mg} / \mathrm{l}$ in mountain lakes to $>100000 \mathrm{mg} / \mathrm{l}$ in evaporative basins $[4,5]$. Chloride in drinking-water originates from natural sources, sewage and industrial effluents, urban runoff containing de-icing salt, and saline intrusion. Chloride concentrations in excess of about $250 \mathrm{mg} / \mathrm{l}$ can give rise to a detectable taste in water [2].

Numerous studies related to the $\mathrm{F}^{-}$content in different rivers around the world have been recently conducted, such as the Ganges-Brahmaputra-Meghna river system, Bangladesh [6], the Humber, Tweed, Wear, Great Ouse,

*corresponding author; e-mail: adembayram@gmail.com and Thames rivers, UK [1], the Animas River, USA [7], the Calabalumba, Seco, and Charbonier rivers, Argentina [8], and the Zhijin River, China [9].

The studies related to the $\mathrm{F}^{-}$content in surface waters from different watersheds of Turkey have been rarely reported. There are reports for the Euphrates River [10] and the Solakl Stream [11]. However, many studies related to the $\mathrm{F}^{-}$content of the drinking waters from different cities of Turkey have been reported, such as reports for Tunceli [12], Edirne [13], Gaziantep [14], and Şanliurfa [15].

\section{Study area}

There are 26 hydrological basins in Turkey. With a share of $9.5 \%$ in total surface runoff, the Eastern Black Sea Basin is the third most important one in the country after the Tigris and Euphrates. The basin covers Ordu, Giresun, Trabzon, Rize and Gümüşhane provinces, where average annual precipitation ranges from $461.3 \mathrm{~mm}$ in Gümüşhane to $2245.3 \mathrm{~mm}$ in Rize. The basin covers subwatersheds such as Melet, Harşit, Değirmendere, Solaklı, İyidere and Firtina (Fig. 1). With a length of $143 \mathrm{~km}$ and a catchment area of $3280 \mathrm{~km}^{2}$, the Harsit Stream is the largest one. There are three hydropower dams, Torul, Kürtün and Aslancık, in operation on the main branch. With a mean annual surface water potential of $560 \times 10^{6} \mathrm{~m}^{3}$, the Değirmendere Stream watershed is of prime importance, since domestic water demand of Trabzon people is supplied by this watershed, where there is a dam, Atasu, in operation on the Galyan Stream. 


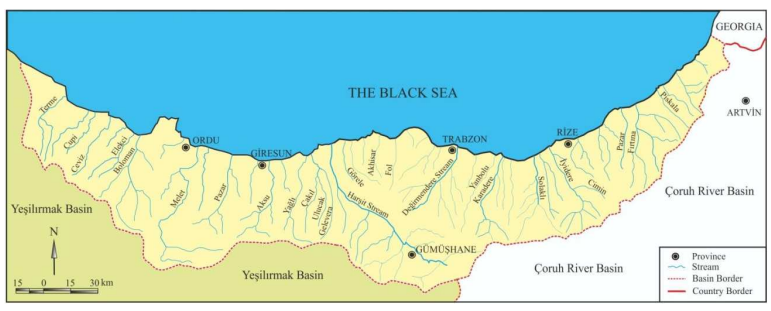

Fig. 1. The Eastern Black Sea Basin, Turkey.

Trabzon province with a total population of 768417 , according to the 2015 census [16], is the most populated city in the Eastern Black Sea Basin. Domestic water demand of the city is supplied by the Degirmendere and Galyan streams, after treatment at the drinking water treatment plants of the Trabzon Metropolitan Municipality.

Gümüşhane province with a total population of 99508 , according to the 2015 census [16], is the least populated city in the Eastern Black Sea Basin. Domestic water demand of the city is supplied by the caisson and deep wells, which are located on the left and right banks of the Harşit Stream, without treatment.

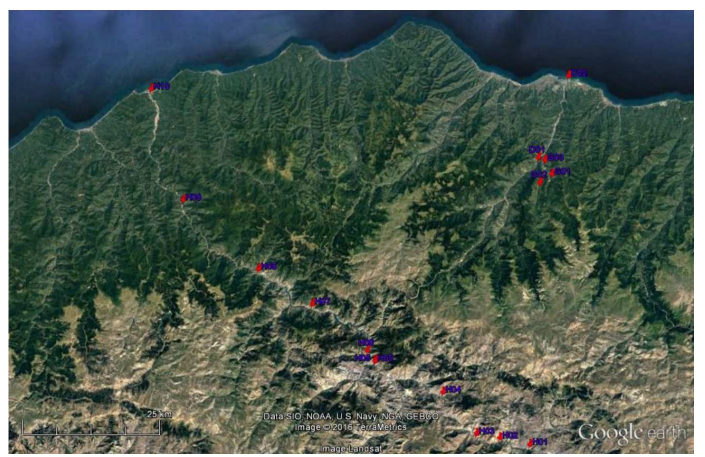

Fig. 2. The study area from the Google Earth, showing the water sampling locations, the Eastern Black Sea Basin.

\begin{tabular}{c|c|c} 
Station & Coordinates & Altitude [m] \\
\hline H01 & $40^{\circ} 24^{\prime} 07.4^{\prime \prime} \mathrm{N}-39^{\circ} 38^{\prime} 29.3^{\prime \prime} \mathrm{E}$ & 1274 \\
$\mathrm{H} 02$ & $40^{\circ} 24^{\prime} 54.0^{\prime \prime} \mathrm{N}-39^{\circ} 34^{\prime} 37.6^{\prime \prime} \mathrm{E}$ & 1234 \\
$\mathrm{H} 03$ & $40^{\circ} 25^{\prime} 23.6^{\prime \prime} \mathrm{N}-39^{\circ} 31^{\prime} 37.7^{\prime \prime} \mathrm{E}$ & 1190 \\
$\mathrm{H} 04$ & $40^{\circ} 29^{\prime} 36.6^{\prime \prime} \mathrm{N}-39^{\circ} 27^{\prime} 30.4^{\prime \prime} \mathrm{E}$ & 1100 \\
$\mathrm{H} 05$ & $40^{\circ} 32^{\prime} 55.7^{\prime \prime} \mathrm{N}-39^{\circ} 18^{\prime} 52.5^{\prime \prime} \mathrm{E}$ & 939 \\
$\mathrm{H} 06$ & $40^{\circ} 33^{\prime} 56.7^{\prime \prime} \mathrm{N}-39^{\circ} 17^{\prime} 54.6^{\prime \prime} \mathrm{E}$ & 910 \\
$\mathrm{H} 07$ & $40^{\circ} 38^{\prime} 41.1^{\prime \prime} \mathrm{N}-39^{\circ} 11^{\prime} 01.4^{\prime \prime} \mathrm{E}$ & 642 \\
$\mathrm{H} 08$ & $40^{\circ} 42^{\prime} 18.5^{\prime \prime} \mathrm{N}-39^{\circ} 04^{\prime} 11.8^{\prime \prime} \mathrm{E}$ & 497 \\
$\mathrm{H} 09$ & $40^{\circ} 49^{\prime} 18.6^{\prime \prime} \mathrm{N}-38^{\circ} 54^{\prime} 42.5^{\prime \prime} \mathrm{E}$ & 154 \\
$\mathrm{H} 10$ & $41^{\circ} 00^{\prime} 16.1^{\prime \prime} \mathrm{N}-38^{\circ} 50^{\prime} 59.7^{\prime \prime} \mathrm{E}$ & 4 \\
$\mathrm{D} 01$ & $40^{\circ} 52^{\prime} 10.9^{\prime \prime} \mathrm{N}-39^{\circ} 41^{\prime} 03.3^{\prime \prime} \mathrm{E}$ & 153 \\
$\mathrm{D} 02$ & $41^{\circ} 00^{\prime} 06.0^{\prime \prime} \mathrm{N}-39^{\circ} 45^{\prime} 25.8^{\prime \prime} \mathrm{E}$ & 3 \\
$\mathrm{G} 01$ & $40^{\circ} 50^{\prime} 31.9^{\prime \prime} \mathrm{N}-39^{\circ} 42^{\prime} 43.4^{\prime \prime} \mathrm{E}$ & 304 \\
$\mathrm{G} 02$ & $40^{\circ} 49^{\prime} 44.5^{\prime \prime} \mathrm{N}-39^{\circ} 41^{\prime} 06.2^{\prime \prime} \mathrm{E}$ & 427 \\
$\mathrm{G} 03$ & $40^{\circ} 51^{\prime} 54.8^{\prime \prime} \mathrm{N}-39^{\circ} 41^{\prime} 53.3^{\prime \prime} \mathrm{E}$ & 175
\end{tabular}

The aim of this study is to monitor the $\mathrm{F}^{-}$content in the Değirmendere Stream watershed, Trabzon Province, and the $\mathrm{F}^{-}$and $\mathrm{Cl}^{-}$contents in the Harşit Stream watershed, Gümüşhane and Giresun provinces, and to evaluate their drinking water quality, with reference to national $[17,18]$ and international $[2,19,20]$ directives and guidelines. The surface water samples (240) were semimonthly collected from 15 water sampling stations: two in the Değirmendere Stream, three in the Galyan Stream, and ten in the Harşit Stream. The sampling stations are shown in Fig. 2, in which the spatial information for each station is given.

\section{Materials and methods}

For the Harşit Stream, the study began in August 2009, was conducted semimonthly, and was completed in February 2010. For the Değirmendere and Galyan streams, the study began in January 2014, was conducted semimonthly, and was completed in November 2014.

Sampling, preservation, and transport of the water samples to the laboratory were done in alignment with the guidelines of the Standard Methods for the Examination of Water and Wastewater [21]. Plastic sample bottles, pre-cleaned with $1 \mathrm{M} \mathrm{HNO}_{3}$ and rinsed with doubledistilled water, were used to collect the water samples.

The surface water samples were filtered through a cellulose acetate membrane filter with a pore size of $0.45 \mu \mathrm{m}$ under negative pressure at the Hydraulic Laboratory, located in Karadeniz Technical University in Trabzon Province.

The $\mathrm{F}^{-}$and $\mathrm{Cl}^{-}$were measured in the laboratory using a UV-vis spectrophotometer, according to the Standard Methods [21]. The analyses were conducted three times for each sample in a temperature-controlled room (21 \pm $\left.2{ }^{\circ} \mathrm{C}\right)$. The final result was presented as the arithmetic mean of the triplicate analyses.

As a part of the study, $\mathrm{F}^{-}$and $\mathrm{Cl}^{-}$contents of the treated waters from the drinking water treatment plants of the Trabzon Metropolitan Municipality are also evaluated. The plants, located on a land of $100000 \mathrm{~m}^{2}$, have a conventional treatment with a capacity of $165000 \mathrm{~m}^{3}$ per day. Conventional treatment consists of the following unit processes: coagulation, flocculation, clarification and filtration, and is typically followed by disinfection at full-scale [22].

\section{Results and discussion}

\subsection{The Değirmendere Stream}

Considering its temporal variation, the $\mathrm{F}^{-}$concentration was at its highest level in the summer and at its lowest level in autumn for both stations. The annual mean value was calculated as $0.156 \mathrm{mg} / \mathrm{l}$ for D01 and $0.200 \mathrm{mg} / \mathrm{l}$ for D02.

The permissible concentration of $\mathrm{F}^{-}$is $1.5 \mathrm{mg} / \mathrm{l}$ in RCWIHC [17] and TS 266 [18], which are complying with the EU [19] and WHO [2], and $2.0 \mathrm{mg} / \mathrm{l}$ in US EPA [20]. Consequently, the values throughout the study period are 
well below the permissible levels, suggested or mandated by several references $[2,17-20]$. However, the stream can be regarded as the fluoride-poor water resource.

Taking into account the spatial variation in the $\mathrm{F}^{-}$ concentration, it was realized that there was an increase of $28 \%$. It is thought that the municipal and industrial wastewater inputs to the stream contribute to the increase.

In a study by Gultekin et al. [23], conducted during a period from March to May 2009, it was reported that the seasonal mean $\mathrm{F}^{-}$concentration was $0.150 \mathrm{mg} / \mathrm{l}$ in the Değirmendere Stream watershed. In another study by Bayram [22], during a period from March 2010 to February 2011, it was reported that the annual mean $\mathrm{F}^{-}$concentration was $0.180 \mathrm{mg} / \mathrm{l}$ for the Değirmendere Stream.

\subsection{The Galyan Stream}

Considering its temporal variations, the $\mathrm{F}^{-}$concentration was at its highest level in the summer and at its lowerst level in autumn for each station. In contrast with the Değirmendere Stream, the order of decreasing $\mathrm{F}^{-}$concentration is Summer $>$Spring $>$Winter $>$Autumn, for each station. The annual mean value was calculated as $0.163 \mathrm{mg} / \mathrm{l}$ for G01, $0.156 \mathrm{mg} / \mathrm{l}$ for G02, and $0.154 \mathrm{mg} / \mathrm{l}$ for G03. Bayram [22] reported that the annual mean $\mathrm{F}^{-}$concentration was $0.203 \mathrm{mg} / \mathrm{l}$ for G03, showing a decrease of $24 \%$ in the past four years.

Similarly, the values throughout the study period are well below the permissible levels, suggested or mandated by national $[17,18]$ and international $[2,19,20]$ directives and guidelines. However, each stream can be also regarded as the fluoride-poor water resource.

\subsection{The drinking water treatment plants of the Trabzon Metropolitan Municipality}

There was no $\mathrm{F}^{-}$data corresponding to the study period because the drinking water treatment plants of the Trabzon Metropolitan Municipality did not monitor or report $\mathrm{F}^{-}$before March 2015. Considering the monthly water-quality reports from March 2015 to August 2016, it was clearly seen that the treated waters had a mean $\mathrm{F}^{-}$concentration of $0.048 \mathrm{mg} / \mathrm{l}$, ranging from 0.010 to $0.120 \mathrm{mg} / \mathrm{l}[24]$.

Considering the monthly water-quality reports corresponding to the study period, it was clearly seen that the treated waters had a mean $\mathrm{Cl}^{-}$concentration of $10.28 \mathrm{mg} / \mathrm{l}$, ranging from 7.47 to $19.00 \mathrm{mg} / \mathrm{l}$ [24]. On the other hand, the treated waters had a mean $\mathrm{Cl}^{-}$concentration of $7.02 \mathrm{mg} / \mathrm{l}$, ranging from 4.60 to $14.00 \mathrm{mg} / \mathrm{l}$, taking into account the monthly water-quality reports from March 2015 to August 2016. The permissible concentration of $\mathrm{Cl}^{-}$is $250 \mathrm{mg} / \mathrm{l}$ in RCWIHC [17] and TS 266 [18], which are complying with the international $[2,19,20]$ directives and guidelines. The treated waters had a $\mathrm{Cl}^{-}$ concentration well below the permissible levels, suggested or mandated by several references [2, 17-20].
Gultekin et al. [23] reported that the seasonal mean $\mathrm{Cl}^{-}$concentration was $5.3 \mathrm{mg} / \mathrm{l}$ in the Değirmendere Stream watershed. Bayram [22] reported that the annual mean $\mathrm{Cl}^{-}$concentration was $3.5 \mathrm{mg} / \mathrm{l}$ for the Değirmendere Stream. These results reveal that the treated waters had higher $\mathrm{Cl}^{-}$concentration than the surface waters. It is believed that these higher concentrations are due to polyaluminum chloride, used for coagulation and flocculation.

\subsection{The Harşit Stream}

Considering its spatial variation, the mean $\mathrm{F}^{-}$concentration was $0.230 \mathrm{mg} / \mathrm{l}$ in $\mathrm{H} 01$, the uppermost station, and showed a decreasing trend along the stream, due to dilution by the tributaries, before the dammed part of the watershed. However, the mean $\mathrm{F}^{-}$concentration was at its highest level in H04, where the untreated urban wastewaters are discharged into the stream, and was $0.296 \mathrm{mg} / \mathrm{l}$. For example, Kaushal et al. [25] have reported that $\mathrm{F}^{-}$concentrations typically increased with distance downstream and with progressive water urbanization in the Gwynns Falls watershed, USA. Increasing $\mathrm{F}^{-}$concentrations were due to contributions of sewage along the Gwynns Falls mainstream.

The mean $\mathrm{F}^{-}$concentration was $0.230 \mathrm{mg} / \mathrm{l}$ in $\mathrm{H} 06$. The last station before the dammed part of the watershed, showed a decreasing trend, again due to the hydraulic residence time in the dammed part, and dropped to $0.141 \mathrm{mg} / \mathrm{l}$ in $\mathrm{H} 10$, the lowermost station.

Taking into account the temporal variation, the $\mathrm{F}^{-}$ concentration was at its highest in autumn and at its lowest in the winter, at most stations in the watershed, with the exception of $\mathrm{H} 09$.

The values throughout the study period are well below the permissible levels, suggested or mandated by several references [2, 17-20]. However, the stream can be regarded as the fluoride-poor water resource.

Considering its spatial variation, the $\mathrm{Cl}^{-}$concentration was at its lowest level in H09 and at its highest level in H04, which is located in the most critical part of the stream. This is also expected, because we know that $\mathrm{Cl}^{-}$ originates from sewage and industrial effluents, as well as from urban runoff, containing de-icing salt and saline intrusion [2]. For example, Vengosh et al. [26] reported that the municipal wastewater from the Dan metropolitan area, Israel, has a $\mathrm{Cl}^{-}$concentration of $350 \mathrm{mg} / \mathrm{l}$. It is thought that the increase in $\mathrm{Cl}^{-}$concentrations in the winter is due to road salt runoff. Gutchess et al. [27] reported that the $\mathrm{Cl}^{-}$concentration in the East and West Branches of the Tioughnioga River, USA, has shown a clear increase over the last few decades, because the road salts have been applied heavily in New York during winter months.

Taking into account the temporal variation, the $\mathrm{Cl}^{-}$ concentration was at its lowest in autumn and at its highest in the winter, in most stations in the watershed, with the exception of $\mathrm{H} 04$.

The permissible concentration of $\mathrm{Cl}^{-}$is $250 \mathrm{mg} / 1$ in RCWIHC [17] and TS 266 [18], which are complying 
with the international $[2,19,20]$ directives and guidelines. Consequently, the $\mathrm{Cl}^{-}$concentrations measured throughout the study period are well below the permissible levels, suggested or mandated by several references $[2,17-20]$.

The basic statistics of the $\mathrm{F}^{-}$and $\mathrm{Cl}^{-}$concentrations for each station are given in Table I.

TABLE I

Fluoride ion concentration in the Değirmendere Stream watershed [28] and fluoride and chloride ion concentrations in the Harşit Stream watershed, the Eastern Black Sea Basin, Turkey.

\begin{tabular}{c|c|c|c|c|c|c|c|c}
\hline \hline & \multicolumn{5}{|c|}{$\mathrm{F}^{-}, \mathrm{mg} / \mathrm{l}$} & \multicolumn{5}{c}{$\mathrm{Cl}^{-}, \mathrm{mg} / \mathrm{l}$} \\
\hline Stations & Min & Max & Mean & SD & Min & Max & Mean & SD \\
\hline D01 & 0.037 & 0.275 & 0.154 & 0.070 & - & - & - & - \\
D02 & 0.049 & 0.339 & 0.200 & 0.077 & - & - & - & - \\
G01 & 0.039 & 0.327 & 0.156 & 0.075 & - & - & - & - \\
G02 & 0.027 & 0.276 & 0.163 & 0.070 & - & - & - & - \\
G03 & 0.036 & 0.294 & 0.156 & 0.075 & - & - & - & - \\
H01 & 0.145 & 0.365 & 0.230 & 0.060 & 1.000 & 5.140 & 2.610 & 1.230 \\
H02 & 0.101 & 0.353 & 0.219 & 0.070 & 1.150 & 3.220 & 2.430 & 0.630 \\
H03 & 0.109 & 0.363 & 0.211 & 0.081 & 2.100 & 3.220 & 2.680 & 0.370 \\
H04 & 0.153 & 0.559 & 0.296 & 0.131 & 2.980 & 15.300 & 6.480 & 4.290 \\
H05 & 0.111 & 0.352 & 0.227 & 0.077 & 1.610 & 3.840 & 2.740 & 0.670 \\
H06 & 0.100 & 0.468 & 0.230 & 0.099 & 1.870 & 3.450 & 2.680 & 0.520 \\
H07 & 0.111 & 0.283 & 0.201 & 0.045 & 1.000 & 3.430 & 2.290 & 0.970 \\
H08 & 0.100 & 0.334 & 0.170 & 0.079 & 1.000 & 3.610 & 2.570 & 0.860 \\
H09 & 0.100 & 0.245 & 0.164 & 0.052 & 1.000 & 3.230 & 2.000 & 0.890 \\
H10 & 0.100 & 0.244 & 0.141 & 0.047 & 1.000 & 4.840 & 2.540 & 1.140
\end{tabular}

\section{Conclusions}

Drinking water is the most important source of fluoride, being an essential micronutrient for humans. The Eastern Black Sea Basin streams are of prime importance, since the water demand of the people in the basin is supplied by these streams, such as Değirmendere, Galyan and Harsit. In this study, the fluoride ion $\left(\mathrm{F}^{-}\right)$and chloride ion $\left(\mathrm{Cl}^{-}\right)$contents of these streams were monitored, and their drinking water quality was evaluated. The main conclusions are as follows.

The $\mathrm{F}^{-}$values throughout the study period for the Değirmendere Stream watershed are well below the permissible levels, suggested or mandated by several references. It was concluded that the water from the drinking water treatment plants of the Trabzon Metropolitan Municipality should be fluoridated, since the Değirmendere and Galyan streams are poor in fluoride, regarding the annual mean $\mathrm{F}^{-}$values of 0.156 and $0.154 \mathrm{mg} / \mathrm{l}$, respectively.

The $\mathrm{F}^{-}$and $\mathrm{Cl}^{-}$values for the Harşit Stream watershed, throughout the study period, are well below the permissible levels, suggested or mandated by several references. Harşit is a stream, impacted by untreated municipal wastewater. Considering the $40 \%$ increase of the $\mathrm{F}^{-}$concentration and $142 \%$ increase of the $\mathrm{Cl}^{-}$concentration, it was concluded that these water-quality variables can be used to directly detect contributions of wastewater inputs to the stream.

Dam construction and operation have various effects on the quality of stream water. The decreases in mean concentration values of $\mathrm{F}^{-}$and $\mathrm{Cl}^{-}$were $29 \%$ and $25 \%$, respectively, in the Harşit Stream. These decreases are probably due to the Torul, Kürtün and Akköy dam reservoirs, where the waters have time for hydraulic residence and are processed by aquatic organisms, which ingest the water.

\section{References}

[1] C. Neal, M. Neal, H. Davies, J. Smith, Sci. Total Environ. 314, 209 (2003).

[2] WHO, World Health Organization, Guidelines for drinking water quality, 3rd ed., Geneva 2004.

[3] S. Vandevijvere, B. Horion, M. Fondu, M.J. Mozin, M. Ulens, I. Huybrechts, H. Van Oyen, A. Noirfalise, Int. J. Environ. Res. Public Health 6, 1676 (2009).

[4] R. Psenner, Aquatic Sci. 51, 108 (1989).

[5] W.R. Kelly, S.V. Panno, K.C. Hackley, H.H. Hwang, A.T. Martinsek, M. Markus, Appl. Geochem. 25, $661(2010)$.

[6] D.K. Datta, L.P. Gupta, V. Subramanian, Environ. Geol. 39, 1163 (2000).

[7] D.J. Bove, K. Walton-Day, B.A. Kimball, Geochem.: Explorat. Environ. Anal. 9, 125 (2009).

[8] M.G. Garcia, K.L. Lecomte, Y. Stupar, S.M. Formica, M. Barrionuevo, M. Vesco, R. Gallara, R. Ponce, Environ. Earth Sci. 65, 535 (2012).

[9] X. Li, P. Wu, Z. Han, J. Shi, Environ. Earth Sci. 75, 981 (2016).

[10] M.T. Alp, M.A.T. Kocer, B. Sen, O. Ozbay, J. Animal Vet. Adv. 9, 2412 (2010).

[11] F. Gultekin, A.F. Ersoy, E. Hatipoglu, S. Celep, Bull. Engin. Geol. Environ. 72, 213 (2013).

[12] V. Demir, S. Ergin, J. Chem. 2013, 238374 (2013).

[13] C. Tokatli, Polish J. Environ. Stud. 23, 2247 (2014).

[14] M. Gunal, A. Kosen, Acta Phys. Pol. A 128, B-107 (2015).

[15] M.I. Yesilnacar, A.D. Yetis, C.T. Dülgergil, M. Kumral, A.D. Atasoy, T.R. Dogan, S.I. Tekiner, I. Bayhan, M. Aydogdu, Environ. Earth Sci. 75, 162 (2016).

[16] TurkStat, Turkish Statistical Institute, https://biruni.tuik.gov.tr/medas $/$ ?kn=95\&locale $=$ en, accessed 19 October 2016.

[17] RCWIHC, Regulation Concerning Water Intended for Human Consumption, The Turkish Official Gazette. no: 25730, Ankara 2005 (in Turkish).

[18] TS 266, Türk Standartları Enstitüsü (TSE), Water intended for human consumption, Ankara 2005 (in Turkish)

[19] EU, Official Journal of European Communities, Council Directive 98/83/EC of 3 November 1998 on the quality of water intended for human consumption, accessed 19 October 2016 (1998).

[20] US EPA, United States Environmental Protection Agency, 2009 Edition of the Drinking Water Standards and Health Advisories, accessed 19 October 2016 (2009). 
[21] APHA, American Public Health Association, Standard methods for the examination of water and wastewater, 18th ed., Washington 1992.

[22] A. Bayram, Desalin. Water Treat. 62, 120 (2017).

[23] F. Gultekin, A.F. Ersoy, E. Hatipoglu, S. Celep, Ekoloji 21, 77 (2012) (in Turkish).

[24] TİSKİ, Trabzon İçmesuyu ve Kanalizasyon İdaresi Genel Müdürlügü, Su Kalite Raporları, accessed 19 October 2016, (2016) (in Turkish).

[25] S.S. Kaushal, K. Delaney-Newcomb, S.E.G. Findlay, T.A. Newcomer, S.W. Duan, M.J. Pennino, G.M. Sivirichi, A.M. Sides-Raley, M.R. Walbridge, K.T. Belt, Biogeochem. 121, 23 (2014).
[26] A. Vengosh, K.G. Heumann, S. Juraske, R. Kasher, Environ. Sci. Technol. 28, 1968 (1994).

[27] K. Gutchess, L. Jin, L. Lautz, S.B. Shaw, X. Zhou, Z. Lu, Sci. Total Environ. 565, 462 (2016).

[28] U. Satilmis, M.Sc. Thesis, Karadeniz Technical University, Trabzon, Turkey 2015. 